\title{
Perbedaan kemampuan berpikir kritis matematis siswa ditinjau dari self-regulated learning
}

\author{
Dendy Maulana Gusmawan', Nanang Priatna \\ Bambang ${ }^{2}$, Avip Priatna Martadiputra3
}

1. Pendidikan Matematika, Universitas Pendidikan Indonesia, Jalan Setiabudhi No. 229, Bandung

2. Ilmu Pengetahuan Alam, Universitas Pendidikan Indonesia, Jalan Setiabudhi No. 229, Bandung *dendymaulana199@gmail.com

Received: o8 Februari 2021; Accepted: 11 Juni 2021; Published: 30 Juni 2021

\begin{abstract}
Abstrak
Kemampuan berpikir kritis merupakan salah satu keterampilan abad 21 (4C) dan kemampuan High Order Thinking Skills (HOTS). Oleh karena itu, kemampuan berpikir kritis matematis sangat penting dikuasai siswa. Sedangkan, berdasarkan laporan TIMSS tahun 2015 dan 2013 ditemukan bahwa kemampuan berpikir kritis siswa Indonesia masih rendah didukung data UNBK 2019 dan beberapa penelitian. Padahal, upaya peningkatan kemampuan berpikir kritis gencar dilakukan pemerintah melalui pengembangan Kurikulum. Artikel ini berupa hasil penelitian dengan tujuan menganalisis ada tidaknya perbedaan kemampuan berpikir kritis matematis siswa ditinjau dari sisi afektif Self-Regulated Learning (SRL). Penelitian ini menggunakan pendekatan kuantitatif dengan metode deskriptif-komparatif. Sampel penelitian ini adalah 105 orang siswa kelas XI salah satu SMAN di Yogyakarta. Data kemampuan berpikir kritis siswa diperoleh dengan menggunakan tes, sedangkan data SRL diperoleh dengan menggunakan angket. Hasil penelitian menunjukkan: 1) ada perbedaan kemampuan berpikir kritis matematis yang signifikan antara siswa dengan kategori SRL rendah, sedang, dan tinggi; 2) ada perbedaan kemampuan berpikir kritis matematis siswa yang signifikan ditinjau dari dimensi SRL, yaitu motivation; time management; self-testing; dan using academic resources. Penelitian ini merupakan dasar acuan untuk mengungkap keterkaitan antara kemampuan berpikir kritis matematis dengan kemampuan SRL siswa.
\end{abstract}

Kata kunci: Perbedaan, Kemampuan berpikir kritis, Self-Regulated Learning

\begin{abstract}
Critical thinking skills is one of the skills in the 21st century (4C) also one of the High Order Thinking Skills (HOTS) abilities. Thus, students need to master mathematical critical thinking skills. However, based on TIMSS reports in 2015 and 2013 supported by the data from UNBK 2019 and several studies, it was found that Indonesian students' critical thinking skills are still low. The efforts in improving critical thinking skills have been done intensively by the government through the development of the Curriculum. This article is a research result that aims to analyze whether there are differences in students' mathematical critical thinking skills reviewed from affective side of Self-Regulated Learning (SRL). This study used a quantitative approach with a comparative descriptive method. The sample of this study were 105 eleventh grade students in one public high school in Yogyakarta. The results showed: 1) there is a significant difference in mathematical critical thinking skills between students with low, medium, and high SRL categories. 2) there is a significant difference in students' mathematical critical thinking skills reviewed from the SRL dimension, which are motivation; time management; self-testing; and using academic resources. The research is a basic reference to reveal the relationship between mathematical critical thinking skills and students' SRL abilities.
\end{abstract}

Keywords: Difference, Critical thinking skills, Self-Regulated Learning 
Dendy Maulana Gusmawan, Nanang Priatna

Bambang Avip Priatna Martadiputra

\section{PENDAHULUAN}

Kemajuan IPTEKS mendorong dunia pendidikan untuk berinovasi baik dari segi proses maupun hasil dari proses pendidikan. Tuntutan pendidikan di abad 21 difokuskan pada aspek kognitif, afektif dan psikomotorik. Salah satu tuntutan kompetensi abad 21 adalah keterampilan berpikir kritis. Berpikir kritis juga merupakan komponen keterampilan berpikir tingkat tinggi (HOTS - High Order Thinking Skill)(Vargas Alfonso, 2015). Ennis (Davies \& Barnett, 2015) mendefinisikan berpikir kritis sebagai berpikir secara reflektif yang beralasan dan difokuskan pada penetapan apa yang dipercayai atau yang dilakukan.

Kemampuan berpikir kritis sangat penting dimiliki siswa bagi negara berkembang seperti Indonesia. Hal tersebut dikarenakan pada era Big Data, keterampilan berpikir kritis diperlukan siswa untuk menghadapi kompleksitas dan ambiguitas informasi yang besar. Oleh sebab itu, siswa perlu dibiasakan untuk berpikir analitis, membandingkan berbagai kondisi, dan menarik kesimpulan untuk dapat menyelesaikan masalah dengan tepat. Hal ini penting sebagai negara berkembang yang masih mengalami euforia teknologi untuk menghindarkan siswa dari penyalahgunaan informasi, mudah termakan berita hoax, dan kurang bertindak teliti.

Hasil studi TIMSS (The Trends International Mathematics and Science Study) tahun 2015 mengenai penguasaan pengetahuan tentang fakta, prosedur, dan konsep pada siswa Indonesia menemukan bahwa, Indonesia menempati urutan ke-44 dari 49 negara (Hadi \& Novaliyosi, 2019). Hasil TIMSS tahun 2015 menunjukkan data siswa dengan kemampuan sains dan domain kognitif (pemahaman, penerapan, dan penalaran) berada pada kategori rendah yaitu sebanyak 54\% siswa Indonesia. Aspek penalaran termasuk pada kemampuan berpikir tingkat tinggi, sedangkan aspek pemahaman termasuk pada kemampuan berpikir dasar (Rofiah et al., 2013). Selain itu, kemampuan penerapan dan penalaran siswa
Indonesia selalu lebih rendah dibandingkan dengan kemampuan pemahamannya. Hal tersebut didukung data hasil UNBK tahun 2016, 2017, dan 2018 (Sumaryanta et al., 2019) yang menunjukkan hasil ujian nasional matematika siswa pada tiga tahun terakhir (2015/2016, 2016/2017, dan 2017/2018) rendah pada seluruh materi yang diujikan, dan secara nasional, hampir seluruh propinsi rata-rata nilai ujian nasional matematika rendah pada seluruh jenjang. Serta pada tahun 2019 (Pusat Penilaian Pendidikan Badan Penelitian dan Pengembangan Kementrian Pendidikan dan Kebudayaan, 2019) yang menunjukkan dari 40 indikator yang diujikan, tiga indikator yang terendah yang mampu dijawab benar oleh siswa adalah; (a) menyelesaikan masalah kontekstual yang berkaitan dengan menggunakan turunan fungsi aljabar; (b) menyelesaikan permasalahan kontekstual yang berkaitan dengan aturan perkalian; (c) menyelesaikan masalah non-rutin berkaitan dengan barisan/deret aritmatika.

Pembuktian pemecahan masalah yang memerlukan penalaran matematis, menemukan, generalisasi atau konjektur, dan menemukan hubungan antara data-data atau fakta yang diberikan merupakan beberapa kegiatan yang dianggap sulit untuk dipelajari bagi siswa dan sulit diajarkan bagi guru di kota Bandung berdasarkan penelitian yang dilakukan oleh TIM Survey IMSTEP-JICA (Fachrurazi, 2011). Apabila ditelaah lebih jauh, kegiatan-kegiatan tersebut merupakan kegiatan yang membutuhkan kemampuan berpikir kritis (Rahmawati et al., 2018). Hal tersebut sejalan dengan hasil dari beberapa penelitian (Hidayat et al., 2016; Puspita \& Jatmiko, 2017) yang dapat diambil kesimpulan bahwa kemampuan berpikir kritis siswa masih rendah.

Secara teoritis, menurut teori sosial kognitif Albert Bandura, prestasi dan kinerja seseorang dipengaruhi oleh faktor dari dalam diri dan lingkungan sekitar (Abdullah, 2019; Bandura, 1991). Kemampuan kognitif berpikir kritis juga dipengaruhi oleh faktor dari dalam diri seseorang dan lingkungannya, dalam hal ini faktor afektif atau sikap dalam mengkondisikan 
diri dan lingkungan. Kemampuan afektif yaitu kemampuan dimana individu secara konsisten mengatur dan mengelola pikiran, emosi, perilaku, dan lingkungan mereka untuk mencapai tujuan akademik yang kemudian disebut dengan kemampuan Self Regulated Learning (SRL) (Boekaerts, 1979; Zimmerman, 1989).

Sejalan dengan teori yang telah dikemukakan, hasil konsensus dari APA (American Philosophical Association) dengan judul "Critical Thinking: A Statement of Expert Consensus for Purposes of Educational Assessment and Instruction" menyimpulkan bahwa SRL merupakan salah satu komponen kemampuan dari berpikir kritis (Facione, 2011). Kemudian, Schraw dkk. (Schraw et al., 2006) menghubungkan antara kemampuan metakognisi, berpikir kritis, dan motivasi dalam satu payung atau rangkaian SRL. Hal ini didukung oleh penemuan Rosario dkk. (Rosário et al., 2019) yang menemukan bahwa siswa yang menggunakan strategi SRL lebih antusias dalam tugas sekolah, menunjukkan kemampuan HOTS yang lebih terlihat, dan pencapaian akademik yang tinggi.

SRL menempatkan siswa untuk bertanggung jawab terhadap proses belajarnya sehingga menjadi lebih menyadari tentang alasan konseptual dan hubungan atau penjelasan pertanyaan yang terjadi selama proses belajar (Sudarman, 2014). Hal ini memungkinkan siswa untuk dapat mengkonstruksi sendiri konsep belajar sesuai dengan dirinya juga solusi terhadap permasalahan yang siswa hadapi secara mandiri, dimana hal ini sejalan dengan pembelajaran Kurikulum 2013, yaitu pembelajaran berpusat pada siswa dan guru hanya sebagai fasilitator.

Kurikulum 2013 juga menuntut siswa untuk memiliki kemampuan afektif yang baik selain kemampuan kognitif. Pada masa pandemi Covid-19 ini, pemerintah menginstruksikan agar pembelajaran disampaikan secara daring. Shih et al. (Shih et al., 2005) selaras dengan Sangsawang (Sangsawang, 2020) menyebutkan bahwa SRL mendukung pembelajaran yang dilaksanakan secara online dimana pengaturan diri dalam belajar atau kemandirian siswa dalam mengatur dirinya untuk belajar sangat berperan penting dalam pembelajaran online untuk memaksimalkan pencapaian belajar siswa, termasuk kemampuan berpikir kritis (Ghanizadeh, 2011; Hidayati \& Kurniati, 2018). Hal ini selaras dengan temuan Alfonso (Alfonso, 2015) dimana ia menemukan bahwa kegiatan berpikir kritis terjadi pada pembelajaran daring seperti aspek berpendapat, analisis, dan motivasi yang dikembangkan oleh guru melalui analisis gambar, video, pertanyaan, dan latihan lainnya.

SRL erat hubungannya dengan kemandirian belajar (Sumarmo, 2002), dan dengan fakta penelitian yang dilakukan oleh Asmar dan Delyana (Asmar \& Delyana, 2020) menemukan adanya hubungan yang positif antara SRL dan kemampuan berpikir kritis siswa, dan penelitian Miatun \& Hikmatul (Miatun \& Hikmatul, 2020) yang menemukan bahwa mahasiswa dengan tingkat SRL tinggi memiliki kemampuan berpikir kritis yang tinggi pula, sehingga disimpulkan bahwa kemampuan SRL sangat relevan dengan pembelajaran daring dimasa pandemi saat ini. Dimana dalam masa pandemi pembelajaran dilakukan secara fully online, namun disisi lain tuntutan akan kemampuan dari output siswa masih perlu dioptimalisasi termasuk kemampuan berpikir kritis. Maka dari itu perlu ditelaah lebih jauh komponen-komponen yang relevan dalam pembelajaran berbasis SRL dengan kemampuan yang dituntut sebagai output pendidikan. Melalui penelitian ini, penulis tertarik untuk melakukan penelaahan tersebut sebagai dasar acuan dalam mengungkap keterkaitan antara kemampuan afektif SRL siswa dengan kemampuan kognitif berpikir kritis matematis siswa dengan judul penelitian adalah "Perbedaan Kemampuan Berpikir Kritis Siswa SMA Ditinjau dari Self Regulated Learning". 


\section{METODE}

Penelitian ini menggunakan pendekatan kuantitatif dengan jenis penelitian deskriptif komparatif. Penelitian deskriptif digunakan untuk mengetahui keberadaan nilai variabel (kelas peristiwa, kondisi, objek, kelompok manusia, atau sistem pemikiran) pada masa sekarang secara mandiri tanpa membuat perbandingan atau menghubungkan dengan variabel lain dengan tujuan membuat deskripsi atau gambaran secara sistematis, faktual, dan akurat mengenai fakta dan sifat fenomena yang diselidiki (Moh, 2011; Sugiyono, 2018). Pendekatan deskriptif dalam penelitian ini digunakan untuk mengetahui gambaran kemampuan berpikir kritis dan kemampuan self-regulation siswa SMA. Pendekatan komparatif menurut Sugiyono (Sugiyono, 2018) adalah metode penelitian yang membandingkan keberadaan satu variabel atau lebih pada dua atau lebih sampel yang berbeda, atau pada waktu yang berbeda. Variabel penelitian dalam penelitian ini adalah kemampuan berpikir kritis matematis sebagai variabel terikat, dan SRL sebagai variabel bebas.

Penelitian ini menggunakan dua instrumen; (1) Tes berpikir kritis matematis; dan (2) Angket SRL. Pengembangan instrumen dilakukan dengan uji coba melalui 20 siswa SMA dan validasi ahli (Dosen Pembimbing). Indikator yang digunakan dalam pengembangan tes berpikir kritis adalah indikator yang dikemukakan Ennis (Lestari et al., 2017), sedangkan indikator yang digunakan untuk pengembangan angket SRL adalah indikator yang dikemukakan oleh Weinstein, Palmer, dan Acee (Weinstein et al., 2016).

Penelitian ini dilakukan di SMA Negeri 3 Yogyakarta dengan sampel penelitian sebanyak 105 orang siswa kelas XI Jurusan IPA. Teknik pengumpulan data secara online karena penelitian diadakan saat pandemi Covid-19, soal tes dan angket disampaikan melalui google form. Siswa diminta untuk mengerjakan soal tes kemampuan berpikir kritis matematis dan mengisi angket SRL dengan waktu yang telah ditentukan. Setelah data terkumpul, data dikategorikan menjadi tiga kelompok kategori; tinggi, sedang, dan rendah. Selanjutnya data dari masing-masing kelompok kategori dianalisis menggunakan uji perbedaan ratarata, sebelum menggunakan metode tertentu dalam menguji perbedaan rata-rata terlebih dahulu digunakan uji prasyarat agar dapat menentukan metode yang tepat dalam pengujian.

\section{HASIL DAN PEMBAHASAN}

\subsection{Deskripsi Data Kemampuan Berpikir Kritis Matematis}

Data kemampuan berpikir kritis matematis siswa yang dilakukan pada siswa dikategorikan sebagai berikut.

Tabel 1. Frekuensi Data Berpikir Kritis Berdasarkan Kategori

\begin{tabular}{lllc}
\hline Kategori & $\begin{array}{l}\text { Interval } \\
(\mathbf{X})\end{array}$ & $\begin{array}{l}\text { Banyak } \\
(\mathbf{N})\end{array}$ & Persentase \\
\hline Rendah & $X<39,68$ & 20 & $19,05 \%$ \\
Sedang & $39,68 \leq X$ & 71 & $67,62 \%$ \\
& $\leq 87,46$ & & \\
Tinggi & $87,46<X$ & 14 & $13,33 \%$ \\
\hline
\end{tabular}

Data diurutkan berdasarkan pada lima indikator berpikir kritis, hasil pengurutan didapat bahwa siswa yang menjadi responden dalam penelitian paling tinggi memperoleh skor pada indikator: (1) advanced clarification dengan prosentase skor 70,24\% jawaban benar, advanced clarification adalah kemampuan siswa dalam merumuskan eksplanatori, kesimpulan, dan hipotesis serta menarik pertimbangan yang bernilai. Diikuti dengan kemampuan (2) elementary clarification dengan prosentase skor $70 \%$ dijawab benar, kemudian (3) inference dengan 63,33\% dijawab benar, (4) basic support dengan 59,52\% dijawab benar. Sedangkan skor yang paling rendah yang diperoleh oleh siswa yang menjadi responden adalah pada aspek indikator (5) strategies and tactics dengan skor $54,76 \%$ dijawab benar, yaitu kemampuan siswa dalam menyusun strategi dalam menetapkan suatu aksi untuk menyelesaikan masalah. 


\subsection{Deskripsi Data Self Regulated Learning}

Hasil pengisian angket SRL dikategorikan sebagai berikut.

Tabel 2. Frekuensi Data SRL Berdasarkan Kategori

\begin{tabular}{llcc}
\hline Kategori & $\begin{array}{l}\text { Interval } \\
(\mathbf{X})\end{array}$ & $\begin{array}{l}\text { Banyak } \\
\text { (N) }\end{array}$ & Persentase \\
\hline Rendah & $X<92,09$ & 23 & $21,9 \%$ \\
Sedang & $\begin{array}{l}91,88 \leq X \\
\text { Tinggi }\end{array}$ & 50 & $47,6 \%$ \\
& $\begin{array}{c}148,85 \\
148,85\end{array}$ & 32 & $30,4 \%$ \\
& $<X$ & & \\
\hline
\end{tabular}

Data diakumulasi berdasarkan tujuh dimensi Self Regulated Learning menurut indikator Weinstein, Palmer, dan Acee (Weinstein et al., 2016). Self-regulation siswa berdasarkan pada dimensi-dimensi yang paling kuat ke paling lemah adalah: (1) Self-Testing (72,95\%); (2) Using Academic Resources (65,96\%); (3) Motivation (64,23\%); (4) Concentration (63,67\%); (5) Attitude (63,14\%); (6) Time Management (60,85\%); dan (7) Anxiety $(55,41 \%)$. Hasil pengurutan akumulasi data didapat bahwa siswa yang menjadi responden dalam penelitian paling tinggi memperoleh skor pada dimensi self-testing, yaitu sikap siswa dalam memonitor diri sendiri dalam kegiatan pembelajaran. Sedangkan skor yang paling rendah dari pengurutan data akumulasi hasil pengisian angket siswa yang menjadi responden adalah pada dimensi anxiety, yaitu sikap siswa dalam mengatasai kecemasan dan kekhawatiran terhadap pembelajaran.

\subsection{Analisis Kemampuan Berpikir Kritis Matematis Ditinjau dari SRL}

Analisis data dilakukan untuk menjawab rumusan masalah mengenai perbedaan kemampuan berpikir kritis matematis antara siswa yang memiliki SRL yang berbeda. Berdasarkan uji hipotesis yang dilakukan pada tahap pengolahan data menggunakan metode Welch ANOVA, diperoleh keputusan bahwa hipotesis penelitian yang diajukan diterima. Dengan kata lain, terdapat perbedaan yang signifikan terhadap hasil tes kemampuan berpikir kritis matematis antara siswa dengan tingkat SRL rendah, sedang, dan tinggi. Selanjutnya, berdasarkan hasil uji post hoc lanjutan pada uji Games-Howell, diketahui bahwa perbandingan rata-rata hasil tes kemampuan berpikir kritis antara siswa dengan tingkat SRL; rendah dan sedang, rendah dan tinggi, serta sedang dan tinggi, masing-masing menunjukkan perbedaan yang signifikan.

Berdasarkan hasil Welch ANOVA dan olah data menggunakan microsft excel, menunjukkan bahwa peringkat nilai rata-rata dari tinggi ke rendah adalah kategori; tinggi, sedang, dan rendah. Siswa dengan SRL yang berada pada kategori tinggi memiliki kemampuan berpikir kritis pada kategori tinggi pula, begitupun dengan siswa yang memiliki SRL dengan kategori sedang memiliki kemampuan berpikir kritis pada kategori sedang dan siswa yang memiliki kemampuan berpikir kritis pada kategori rendah memiliki kemampuan berpikir kritis pada kategori rendah. Hal ini mengindikasikan adanya hubungan yang proporsional antara SRL siswa dengan kemampuannya dalam berpikir kritis.

Adapun hubungan dari kemampuan berpikir kritis matematis dan SRL dari data yang diperoleh berada pada kategori 'kuat'. Hal ini didasarkan pada pengkategorian nilai koefisien korelasi menurut Sugiyono (Sugiyono, 2018). Hasil ini selaras dengan hasil penelitian yang dilakukan Miatun dan Hikmatul (Miatun \& Hikmatul, 2020) yang berkesimpulan bahwa terdapat perbedaan signifikan kemampuan berpikir kritis mahasiswa ditinjau dari tingkat SRL, dimana mahasiswa dengan SRL tinggi memiliki kemampuan berpikir kritis yang lebih baik daripada mahasiswa dengan SRL sedang dan rendah, serta mahasiswa dengan SRL sedang memiliki kemampuan berpikir kritis yang lebih baik daripada mahasiswa dengan SRL rendah. Lebih jauh, kerangka SRL berhasil dijadikan kerangka untuk menyusun suatu instrumen aktivitas pembelajaran yang meningkatkan kemampuan berpikir kritis (Sangsawang, 2020). 
Data diperoleh dari instrumen yang dikerjakan siswa secara daring melalui google form. Teknik tersebut digunakan untuk mensiasati ketidakmungkinan penyelenggaraan tes secara langsung dan tatap muka dimasa pandemi Covid-19. Hasil responden dari subjek penelitian direduksi dikarenakan hasil tes berpikir kritis yang dianggap tidak valid dan dihapus dari data yang diolah. Subjek yang dinyatakan tidak valid adalah subjek yang tidak memperoleh skor. Hal ini dikarenakan subjek tidak berpartisipasi dalam pelaksanaan tes.

Alasan dari ketidakikutsertaan subjek dalam pelaksanaan tes sudah cukup untuk menggugurkan subjek dari data keseluruhan. Dalam sebuah penelitian, hal ini dinamakan sebagai bias seleksi. Walaupun uji coba ini dilakukan pada siswa berlatar belakang sama yaitu siswa kelas XI IPA di salah satu SMA Negeri di Kota Yogyakarta dan siswa mengerjakan soal dengan pembatasan waktu pada jam pelajaran daring sekolah, namun peneliti tidak dapat mengabaikan kemungkinan siswa mengerjakan soal tes dengan dibantu atau bekerja sama dengan pihak lain.

\subsection{Analisis Kemampuan Berpikir Kritis} Matematis Ditinjau dari Dimensi SRL

Analisis data dilakukan untuk meneliti lebih dalam mengenai perbedaan kemampuan berpikir kritis matematis antara siswa ditinjau dari dimensi SRL. Berdasarkan uji hipotesis yang dilakukan pada tahap pengolahan data menggunakan merode Kruskal Wallis $H$ test, diperoleh kesimpulan bahwa skor hasil tes kemampuan berpikir kritis yang ditinjau dari tujuh dimensi yang berbeda, masing-masing memberikan hasil yang sama. Terdapat perbedaan kemampuan berpikir kritis matematis yang signifikan antara siswa dengan tingkat tiap dimensi SRL rendah, sedang, dan tinggi.

Dilakukan uji post hoc lanjutan dengan metode Dunn-Benferroni pada skor tes berpikir kritis matematis siswa yang ditinjau dari dimensi attitude. Perbandingan rata-rata hasil tes kemampuan berpikir kritis siswa antar kategori dalam dimensi attitude, tidak ada perbedaan yang signifikan antara kategori rendah-sedang, sedangkan perbandingan untuk siswa dengan kategori rendah-tinggi, serta sedang-tinggi, menunjukkan perbedaan yang signifikan. Selanjutnya berdasarkan hasil mean rank uji Kruskal Wallis, didapatkan bahwa peringkat nilai rata-rata kemampuan berpikir kritis matematis dari tinggi ke rendah adalah kategori; tinggi, sedang, dan rendah.

Berdasarkan skor tes berpikir kritis matematis siswa yang ditinjau dari dimensi motivation, didapatkan hasil uji perbandingan rata-rata hasil tes kemampuan berpikir kritis antara siswa dengan kategori dimensi motivation rendah-sedang, rendah-tinggi, serta sedangtinggi, masing-masing menunjukkan perbedaan yang signifikan. Selanjutnya berdasarkan hasil mean rank uji Kruskal Wallis, didapatkan bahwa peringkat nilai rata-rata kemampuan berpikir kritis matematis dari tinggi ke rendah adalah kategori; tinggi, sedang, dan rendah.

Berdasarkan skor tes berpikir kritis matematis siswa yang ditinjau dari dimensi anxiety. Perbandingan rata-rata hasil tes kemampuan berpikir kritis siswa antar kategori dalam dimensi anxiety, tidak ada perbedaan yang signifikan antara kategori rendah-sedang, sedangkan perbandingan untuk siswa dengan kategori rendah-tinggi, serta sedang-tinggi, menunjukkan perbedaan yang signifikan. Selanjutnya berdasarkan hasil mean rank uji Kruskal Wallis, didapatkan bahwa peringkat nilai rata-rata kemampuan berpikir kritis matematis dari tinggi ke rendah adalah kategori; tinggi, sedang, dan rendah.

Secara umum kemampuan berpikir kritis matematis siswa yang ditinjau dari dimensi concentration menunjukkan perbedaan yang tidak signifikan. Sedangkan perbandingan ratarata skor tes siswa dengan kategori dimensi concentration rendah-tinggi serta sedangtinggi, masing-masing menunjukkan perbedaan yang signifikan. Selanjutnya, hasil mean rank uji Kruskal Wallis menunjukkan bahwa 
peringkat nilai rata-rata kemampuan berpikir kritis matematis dari tinggi ke rendah adalah kategori; tinggi, sedang, dan rendah.

Kemudian skor tes berpikir kritis matematis siswa yang ditinjau dari dimensi Time Management, didapatkan hasil uji perbandingan rata-rata hasil tes kemampuan berpikir kritis antara siswa dengan kategori dimensi time management rendah-sedang, rendah-tinggi, serta sedang-tinggi, masingmasing menunjukkan perbedaan yang signifikan. Selanjutnya, hasil mean rank uji Kruskal Wallis menunjukkan bahwa peringkat nilai rata-rata kemampuan berpikir kritis matematis dari tinggi ke rendah adalah kategori: tinggi, sedang, dan rendah.

Berdasarkan skor tes berpikir kritis matematis siswa yang ditinjau dari dimensi Self-Testing, didapatkan hasil uji perbandingan rata-rata skor tes dari masing-masing kategori menunjukkan perbedaan yang signifikan satu sama lain. Selanjutnya berdasarkan hasil mean rank uji Kruskal Wallis, didapatkan bahwa peringkat nilai rata-rata kemampuan berpikir kritis matematis dari tinggi ke rendah adalah kategori; Tinggi, Sedang, dan Rendah.

Berdasarkan skor tes berpikir kritis matematis siswa yang ditinjau dari dimensi using academic resources. Perbandingan rata-rata hasil tes kemampuan berpikir kritis siswa antar kategori dalam dimensi using academic resources, perbandingan untuk siswa dengan kategori rendah dan sedang, serta sedang dan tinggi, menunjukkan perbedaan yang signifikan, tidak ada perbedaan yang signifikan antara kategori sedang tinggi. Selanjutnya berdasarkan hasil mean rank uji Kruskal Wallis, didapatkan bahwa peringkat nilai ratarata kemampuan berpikir kritis matematis dari tinggi ke rendah adalah kategori; tinggi, sedang, dan rendah.

Agar lebih memperjelas gambaran perbedaan rata-rata tes berpikir kritis antara ketiga kategori yang ditinjau dari dimensi SRL, maka kesimpulan hasil uji perbedaan rata-rata tersebut dirangkum pada Tabel 3 .

Tabel 3. Rekap Hasil Uji Post-Hoc Data Tes Berdasarkan Tiap Kategori Dimensi SRL

\begin{tabular}{|c|c|c|c|}
\hline \multirow[b]{2}{*}{$\begin{array}{l}\text { Dimensi } \\
\quad S R L\end{array}$} & \multicolumn{3}{|c|}{ Hasil Uji Perbedaan Rata-Rata } \\
\hline & $\begin{array}{l}\text { Rendah- } \\
\text { Sedang }\end{array}$ & $\begin{array}{l}\text { Rendah- } \\
\text { Tinggi }\end{array}$ & $\begin{array}{c}\text { Sedang- } \\
\text { Tinggi }\end{array}$ \\
\hline Attitude & $\begin{array}{c}\text { Tidak } \\
\text { signifikan } \\
\text { berbeda }\end{array}$ & $\begin{array}{c}\text { Signifikan } \\
\text { berbeda }\end{array}$ & $\begin{array}{c}\text { Signifikan } \\
\text { berbeda }\end{array}$ \\
\hline Motivation & $\begin{array}{c}\text { Signifikan } \\
\text { berbeda }\end{array}$ & $\begin{array}{c}\text { Signifikan } \\
\text { berbeda }\end{array}$ & $\begin{array}{c}\text { Signifikan } \\
\text { berbeda }\end{array}$ \\
\hline Anxiety & $\begin{array}{c}\text { Tidak } \\
\text { signifikan } \\
\text { berbeda }\end{array}$ & $\begin{array}{c}\text { Signifikan } \\
\text { berbeda }\end{array}$ & $\begin{array}{c}\text { Signifikan } \\
\text { berbeda }\end{array}$ \\
\hline Concentration & $\begin{array}{c}\text { Tidak } \\
\text { signifikan } \\
\text { berbeda }\end{array}$ & $\begin{array}{c}\text { Signifikan } \\
\text { berbeda }\end{array}$ & $\begin{array}{c}\text { Signifikan } \\
\text { berbeda }\end{array}$ \\
\hline $\begin{array}{c}\text { Time } \\
\text { Management }\end{array}$ & $\begin{array}{c}\text { Signifikan } \\
\text { berbeda }\end{array}$ & $\begin{array}{l}\text { Signifikan } \\
\text { berbeda }\end{array}$ & $\begin{array}{c}\text { Signifikan } \\
\text { berbeda }\end{array}$ \\
\hline Self-Testing & $\begin{array}{c}\text { Signifikan } \\
\text { berbeda }\end{array}$ & $\begin{array}{l}\text { Signifikan } \\
\text { berbeda }\end{array}$ & $\begin{array}{c}\text { Signifikan } \\
\text { berbeda }\end{array}$ \\
\hline $\begin{array}{c}\text { Using } \\
\text { Academic } \\
\text { Resources }\end{array}$ & $\begin{array}{c}\text { Signifikan } \\
\text { berbeda }\end{array}$ & $\begin{array}{c}\text { Signifikan } \\
\text { berbeda }\end{array}$ & $\begin{array}{c}\text { Tidak } \\
\text { signifikan } \\
\text { berbeda }\end{array}$ \\
\hline
\end{tabular}

Hasil ranking dari masing-masing kategori pada tiap dimensi SRL memperoleh peringkat rank yang sama yaitu peringkat pertama adalah kategori tinggi, peringkat dua adalah kategori sedang, dan peringkat tiga adalah kategori rendah.

Temuan ini selaras dengan temuan penelitian Rosario dkk. (Rosário et al., 2019) yang menemukan bahwa pembelajaran yang disajikan dalam kerangka SRL memenuhi tuntutan kemampuan siswa dalam mencapai tantangan akademisnya seperti; time management, procrastination, note-taking, academic distracters, dan goal setting. Juga memfasilitasi peningkatan kemampuan berpikir kritisnya.

\section{KESIMPULAN}

Kemampuan siswa dalam menetapkan suatu strategi dan taktik untuk menyelesaikan masalah dan membangun keterampilan atau pemahaman untuk mempertimbangkan kebenaran dari suatu informasi masih rendah. Namun siswa cukup mahir dalam 
memfokuskan diri pada pertanyaan, argumen, atau masalah untuk selanjutnya merumuskan hipotesis dan klarifikasi lanjutan. Kecemasan siswa terhadap pembelajaran masih tinggi dan belum mampu mengatur waktu belajarnya secara mandiri. Selain itu, siswa masih kesulitan dalam menentukan tujuan (goal) belajarnya sesuai dengan kemampuan diri, sehingga kesadaran siswa akan pentingnya pembelajaran masih cukup rendah. Namun, kepercayaan diri serta keyakinan siswa akan kemampuan diri dalam mengikuti pembelajaran juga mencapai suatu kriteria sudah terbentuk cukup baik. Siswa juga sudah cukup baik dalam memanfaatkan berbagai macam media untuk mencari bahan pembelajaran. Sedangkan, kesadaran siswa dalam memonitor diri dalam kegiatan pembelajaran terbentuk sangat baik dalam diri siswa.

Terdapat perbedaan skor hasil tes berpikir kritis matematis yang signifikan antara siswa yang ditinjau dari SRL. Lebih lanjut, skor tes berpikir kritis matematis siswa yang tingkat SRL-nya berkategori rendah signifikan berbeda dengan siswa yang tingkat SRL-nya sedang; skor tes berpikir kritis matematis siswa yang tingkat SRL-nya berkategori rendah signifikan berbeda dengan siswa yang tingkat SRL-nya tinggi; skor tes berpikir kritis matematis siswa yang tingkat SRL-nya berkategori sedang signifikan berbeda dengan siswa yang tingkat SRL-nya tinggi. Sehingga, dengan kata lain disimpulkan bahwa siswa dengan tingkat SRL yang tinggi memiliki tingkat kemampuan berpikir kritis yang tinggi pula begitupun seterusnya.

Terdapat perbedaan skor hasil tes berpikir kritis matematis yang signifikan antara siswa ditinjau dari tiap-tiap dimensi SRL. Peninjauan dari seluruh dimensi SRL menunjukkan adanya perbedaan rata-rata hasil tes berpikir kritis yang signifkan. Uji lanjutan untuk mengetahui perbedaan rata-rata skor berpikir kritis matematis, pada masing-masing dimensi SRL dengan kategori tinggi, sedang, dan rendah sebagian besar menunjukkan perbedaan yang signifikan. Hanya beberapa perbandingan ratarata skor pasangan kategori (pairwise comparison) yang tidak menunjukkan perbedaan yang signifikan, yaitu; dimensi attitude antara kategori rendah-sedang; dimensi anxiety antara kategori rendah-sedang; dimensi concentration antara kategori rendahsedang; dimensi using academic resources antara kategori sedang-tinggi. Walaupun secara perhitungan statistik terdapat beberapa perbandingan rata-rata yang tidak signifikan berbeda, namun nilai rata-rata masing-masing kategori pada tiap dimensi berbeda. Secara hirarkis, rata-rata skor tes berpikir kritis matematis siswa ditinjau dari tiap dimensi SRL menunjukkan susunan yang sama yaitu (besar ke kecil); kategori tinggi, sedang, rendah.

\section{REFERENSI}

Abdullah, S. M. (2019). Social cognitive theory : a bandura thought review published in 1982-2012. Psikodimensia, 18(1), 85. https://doi.org/10.24167/psidim.v18i1.17 o8

Asmar, A., \& Delyana, H. (2020). Hubungan kemandirian belajar terhadap kemampuan berpikir kritis melalui penggunaan software geogebra. AKSIOMA: Jurnal Program Studi Pendidikan Matematika, 9(2), 221. https://doi.org/10.24127/ajpm.v9i2.2758

Bandura, A. (1991). Social cognitive theory of self-regulation. Organizational Behavior and Human Decision Processes, 5o(2), 248-287. https://doi.org/10.1016/07495978(91)90022-L

Boekaerts, M. (1979). Self-regulation in the classroom: A perspective on assessment and intervention. Applied Psychology, 54(2), 199-231.

Davies, M., \& Barnett, R. (2015). The palgrave handbook of critical thinking in higher education. The Palgrave Handbook of Critical Thinking in Higher Education, 125. https://doi.org/10.1057/9781137378057

Fachrurazi. (2011). Penerapan pembelajaran 
Perbedaan kemampuan berpikir kritis matematis siswa ditinjau dari self-regulated learning

berbasis masalah untuk meningkatkan kemampuan berpikir kritis dan komunikasi matematis siswa sekolah dasar. Jurnal Penelitian Pendidikan UPI, Edisi Khus(1), 76-89. http://jurnal.upi.edu/penelitianpendidikan/view/637/

Facione, P. a. (2011). Critical thinking: what it is and why it counts. in insight assessment (Issue ISBN 13: 978-1-891557-07-1.). https://www.insightassessment.com/CTResources/Teaching-For-and-AboutCritical-Thinking/Critical-ThinkingWhat-It-Is-and-Why-It-Counts/CriticalThinking-What-It-Is-and-Why-It-CountsPDF

Ghanizadeh, A. (2011). An investigation into the relationship between self-regulation and critical thinking among iranian efl teachers. Technology of Education, 5(3), 213-221.

Hadi, S., \& Novaliyosi. (2019). TIMSS Indonesia (Trends in International Mathematics and Science Study). Prosiding Seminar Nasional \& Call For Papers Program Studi Magister Pendidikan Matematika Universitas Siliwangi, 562-569.

Hidayat, A., Rahayu, S., \& Rahmawati, I. (2016). Analisis keterampilan berpikir kritis siswa smp pada materi gaya dan penerapannya. In Pros. Semnas Pend. IPA Pascasarjana $U M$ (Vol. 1, pp. 1112-1119).

Hidayati, D. W., \& Kurniati, L. (2018). The influence of self regulated learning to mathematics critical thinking ability on $3 \mathrm{~d}$ shapes geometry learning using geogebra. JIPM (Jurnal Ilmiah Pendidikan Matematika), $7(1), \quad 40$. https://doi.org/10.25273/jipm.v7i1.2965

Lestari, K. E., Yudhanegara, M. R., Studi, P., Matematika, P., Karawang, U. S., \& Barat, J. (2017). Analisis Adaptive reasoning proficiency mahasiswa melalui implementasi teori conditioningreinforcement-scaffolding (crs) pada mata kuliah analisis real. JP3M (Jurnal
Penelitian Pendidikan Dan Pengajaran Matematika), 3(2), 77-82. http://jurnal.unsil.ac.id/index.php/jp3m/ article/view/257

Miatun, A., \& Hikmatul, K. (2020). Pengaruh geogebra online berbasis scaffolding dan tingkat self-regulated learning terhadap kemampuan berpikir kritis. 15(2), 124136.

Moh, N. (2011). Metode penelitian (6th ed.). Penerbit Ghalia.

Pusat Penilaian Pendidikan Badan Penelitian dan Pengembangan Kementrian Pendidikan dan Kebudayaan. (2019). Laporan hasil ujian nasional 2019. Kementrian Pendidikan Dan Kebudayaan. https://hasilun.puspendik.kemdikbud.go. id/

Puspita, A. T., \& Jatmiko, B. (2017). Implementasi model pembelajaran inkuiri terbimbing ( guided inquiry) terhadap keterampilan berpikir kritis siswa pada pembelajaran fisika materi fluida statis kelas XI di SMA Negeri 2 Sidoarjo Asri Trisna Puspita , Budi Jatmiko Abstrak. O2(03), 121-125.

Rahmawati, A. Y., Rohaeti, E. E., \& Yuliani, A. (2018). Analisis kemampuan berpikir kritis matematis ditinjau dari kemandirian belajar siswa kelas xi melalui pendekatan metakognitif. JPMI (Jurnal Pembelajaran Matematika Inovatif), 1(4), 607. https://doi.org/10.22460/jpmi.v1i4.p607616

Rofiah, E., Nonoh, s. A., \& Ekawati, E. Y. (2013). Penyusunan instrumen tes kemampuan berpikir tingkat tinggi fisika pada siswa SMP Oleh: Emi Rofiah, Nonoh Siti Aminah, Elvin Yusliana Ekawati Program Studi Pendidikan Fisika Fakultas Keguruan dan Ilmu Pendidikan Universitas Sebelas Maret. Jurnal Pendidikan Fisika, 1(2), 17-22.

Rosário, P., Núñez, J. C., \& Magalhães, P. (2019). Improving college students' critical thinking through the use of a story 
tool for self-regulated learning training (1st ed., pp. 193-207). Routledge. https://www.taylorfrancis.com/chapters/i mproving-college-students-criticalthinking-use-story-tool-self-regulatedlearning-training-pedro-rosário-josécarlos-núñez-paula-magalhães-soniafuentes-cleidilene-magalhães-kylebusing/e/10.4324/9780429323058-12

Sangsawang, T. (2020). An instructional design for online learning in vocational education according to a self-regulated learning framework for problem solving during the covid-19 crisis. Indonesian Journal of Science and Technology, 5(2), 283-198. https://doi.org/10.17509/ijost.v5i2.24702

Schraw, G., Crippen, K. J., \& Hartley, K. (2006). Promoting self-regulation in science education: Metacognition as part of a broader perspective on learning. Research in Science Education, 36(1-2), 111-139. https://doi.org/10.1007/s11165-005-39178

Shih, K. P., Chang, C. Y., Chen, H. C., \& Wang, S. S. (2005). A self-regulated learning system with scaffolding support for selfregulated e/m-learning. ITRE 2005 - 3rd International Conference on Information Technology: Research and Education Proceedings, 2005, 30-34. https://doi.org/10.1109/ITRE.2005.1503 060

Sudarman. (2014). Pengaruh strategi pembelajaran blended learning terhadap perolehan belajar konsep dan prosedur. Jurnal Pendidikan Dan Pembelajaran, 21(3), 11.

Sugiyono. (2018). Metode penelitian kuantitatif, kualitatif, dan $r \& d$. Alfabeta.

Sumarmo, U. (2002). Kemandirian belajar: apa, mengapa, dan bagaimana dikembangkan pada siswa. Seminar Nasional FMIPA UNY 2002, 1983, 1-9.

Sumaryanta, S., Priatna, N., \& Sugiman, S. (2019). Mapping of the result of mathematics. Indonesian Digital Journal of Mathematics and Education, 6, 543557.

http://p4tkmatematika.kemdikbud.go.id/ journals/index.php/idealmathedu/

Vargas Alfonso, D. (2015). Evidence of critical thinking in high school humanities classrooms. GiST Education and Learning Research Journal, 11(11), 26-44. https://doi.org/10.26817/16925777.281

Weinstein, C. E., Palmer, D. R., \& Acee, T. W. (2016). Learning and study strategies inventory LASSI third edition user's manual 3rd Edition. H\&H Publishing Company, Inc., $1-55$. www.hhpublishing.com

Zimmerman, B. J. (1989). A social cognitive view of self-regulated academic learning. Journal of Educational Psychology, 81(3), 329-339. https://doi.org/10.1037/00220663.81.3.329 